\title{
Landscape and tree community effects on the infestation of an endemic fungal pathogen in riparian forests were mediated by leaf traits
}

Binli Wang

Beijing Forestry University

Chengming Tian

Beijing Forestry University

Yingmei Liang ( $\square$ liangym@bjfu.edu.cn )

Beijing Forestry University https://orcid.org/0000-0002-1690-5512

\section{Research}

Keywords: Disease prevalence, Disease severity, Host density, Forest cover, Leaf traits, Marssonina leaf spot of poplar, Pathogen load, Tree diversity

Posted Date: September 28th, 2021

DOI: https://doi.org/10.21203/rs.3.rs-917450/v1

License: (a) (1) This work is licensed under a Creative Commons Attribution 4.0 International License. Read Full License 


\section{Abstract \\ Background}

Plant pathogens are regarded as crucial agents shaping the dynamics of natural forest communities. Marssonina leaf spot of poplar is induced by an endemic pathogenic fungus Drepanopeziza populi, causing increased damage to riparian poplar stands in recent years. However, such endemic fungal diseases have received little attention at the landscape scale, despite the key role of landscape heterogeneity in the development and spread of emerging forest diseases. Moreover, most studies have insufficiently captured multiple ecological factors driving the infestation of an endemic pathogen acting at the landscape, community, and individual scales.

\section{Methods}

We measured pathogen load, disease prevalence, and disease severity of Marssonina leaf spot in poplars in riparian forests. We explored the direct and indirect effects of multiple ecological factors on pathogen infestation using a path analysis. Specifically, we first assessed the effects of landscape and community factors on leaf traits including leaf area, specific leaf area (SLA) and leaf dry matter content (LDMC), and then examined the role of these factors in shaping disease dynamics.

\section{Results}

Path analysis showed that landscape features had no direct impact on leaf traits and pathogen infestation, but directly affected tree community composition. Landscapes with higher forest cover resulted in higher host density and tree diversity. Host density was the most important factor of pathogen load, with higher host density resulting in more symptomatic leaves. Tree diversity had direct effects on disease prevalence, with poplars growing in mixed forest stands far less affected by pathogens than in pure stands. Moreover, disease prevalence was positively related to pathogen load. Tree diversity strongly reduced SLA, but increased LDMC. Higher SLA was found to increase pathogen load and disease severity, but higher LDMC was found to reduce both of them.

\section{Conclusions}

Our results show that the effects of landscape and tree community on Marssonina leaf spot disease are mediated by leaf traits. Disentangling the effects of biotic and abiotic factors affecting pathogen infestation contributes to reduce the overall impact of this disease, which can provide policy makers with sustainable management of endemic plant diseases in natural forests.

\section{Racknround}

Loading [MathJax]/jax/output/CommonHTML/jax.js 
Plant pathogens play an important role in shaping natural forest ecosystems, and most pathogens of forest trees have co-evolved for eons with their hosts, reaching a sort of balance between them and populations of susceptible tree species (Castello et al. 1995; Burgess and Wingfield 2017). In this sense, endemic fungal pathogens can affect many forest ecosystem processes and contribute to maintaining the dynamics and diversity of forests by reducing abundance of host trees or by altering competition outcomes among host and non-host tree species (Hansen 1999; Holdenrieder et al. 2004; Paap et al. 2018). However, anthropogenic activities and climate changes are enhancing occurrence and severity of certain endemic plant diseases, which are either the type not normally thought of as highly virulent or are those that have not been previously reported as a serious problem on a particular host (Sturrock et al. 2011; Pautasso et al. 2015; Paap et al. 2017b; Assefa and Abate 2018). While previous studies focused on emerging plant diseases, elucidating the role of ecological drivers on damaging endemic diseases has become an increasingly important area requiring further research under non-outbreak conditions (Condeso and Meentemeyer 2007; Ghelardini et al. 2016). Reducing infestation of endemic fungal pathogens requires disentangling the effects of biotic and abiotic factors on disease prevalence and severity in host trees.

Disease spread and severity fundamentally depend on the overlap of a pathogen, susceptible hosts, and abiotic environmental conditions that are favorable for disease (i.e. disease triangle;Scholthof 2007). Importantly, abiotic factors such as physical landscape structure can directly or indirectly affect the hostpathogen interactions that lead to plant disease (Dillon and Meentemeyer 2019; Grosdidier et al. 2020). Ecologists have increasingly focused on the reciprocal interactions between spatial patterns and ecological processes at a landscape scale over the past 30 years (Turner 1989, 2005). But this approach has not been applied sufficiently to forest pathology of endemic diseases, as most ecologists were interested in landscape epidemiology of emerging infectious diseases, aiming to determine how spatial patterns shape disease severity (Castello et al. 1995; Condeso and Meentemeyer 2007; Plantegenest et al. 2007; Meentemeyer et al. 2012). The spatial composition and configuration of host vegetation is of great importance for pathogens affecting long-lived hosts such as forest trees (Condeso and Meentemeyer 2007), and thus landscape features have been increasingly recognized as important factors of pathogen spread and severity in a spatially heterogeneous environment (Holdenrieder et al. 2004; Ferrenberg 2016; Cobb and Metz 2017). In this way, landscape features not only affect the spread of invasive pathogens (Meentemeyer et al. 2012; Grosdidier et al. 2020), but are crucial to disease expression of endemic pathogens. A landscape-scale study, for instance, revealed that local biotic and abiotic processes contribute to the incidence of an endemic canker pathogen in marri in Australia (Paap et al. 2017a).

Within habitat patches, fungal pathogen infestation on host trees is affected by tree community composition which could change focal tree's physical and chemical apparency and anti-pathogen defences (Hantsch et al. 2013; Hantsch et al. 2014a; Setiawan et al. 2014; Field et al. 2020). Specifically, declining damage to hosts with increasing tree species diversity can be expected for plant-fungal pathogen relationships, as most fungal pathogens are highly specialized on one single tree species (Keesing et al. 2006; Benítez et al. 2013; Hantsch et al. 2013), making them exclusively dependent on the Loading [MathJax]/jax/output/CommonHTML/jax.js nsity of host tree species) (Hantsch et al. 2014a). Although 
tree community effects on fungal pathogens are crucial to our understanding of multitrophic interactions and biodiversity functioning (Hansen 1999; Scherber et al. 2010), only a few studies on forest disease have explicitly assessed the role of tree diversity and density effects on endemic pathogen infestation (Benítez et al. 2013; Nguyen et al. 2016). Furthermore, landscape features and land-use changes are known to affect host density by influencing where hosts aggregate, and the aggregation of tree hosts is particularly determined by landscape structure since trees don't move (Meentemeyer et al. 2008; ArroyoRodríguez et al. 2016). Habitat patches where conditions are favorable tend to increase host density, thereby affecting pathogen infection (Dillon and Meentemeyer 2019).

Landscape and tree community characteristics affecting disease prevalence/severity are rather well studied in certain plant disease systems (Jactel et al. 2009; Meentemeyer et al. 2012; Haas et al. 2016; Dillon and Meentemeyer 2019; Grosdidier et al. 2020), however, there is only limited knowledge about the effect of plant morphological characteristics on fungal pathogen infestation (Toome et al. 2010). Tree leaves may be more susceptible to pathogen damage with leaf aging, and the infestation always starts from lower leaves and is greater on leaves with higher wettability (McCracken and Dawson, 1992; Pinon et al. 2006). A common leaf characteristic that describes leaf morphology is specific leaf area (SLA), and leaves with high SLA tend to be more preferred by fungal pathogens such as leaf rust (Poorter et al. 2009; Toome et al. 2010). In addition, light availability for a focal plant might vary with tree diversity as hosts are surrounded by non-host plants of differing growth rates (Muiruri et al. 2019), which in turn affect leaf traits related to light acquisition (e.g., leaf size and SLA; Al Afas et al. 2007). Thus, leaf traits may vary across gradients of the host density and tree species diversity.

Nevertheless, little currently is known of tree community effects on fungal pathogens via changes in leaf traits, and none have been able to demonstrate a direct link between landscape features, tree community composition, leaf traits and disease prevalence/severity. Landscape-scale pattern of host habitat, such as forest cover, may cause variations in tree community composition (Morante-Filho et al. 2016), divergences among individual trees in strategically important leaf traits (Krix and Murray 2018), and, indirectly, pathogen damage (Dillon and Meentemeyer 2019). Therefore, assessing the effects of key biotic and abiotic factors on endemic fungal pathogens requires quantifying the relative contributions of leaf trait-dependent and independent effects of landscape and community characteristics on pathogen load, disease prevalence and disease severity. These interactions present analytical challenges to understand the complex nature of direct and indirect causal relationships, and we addressed this challenge using path analysis to analyze the influence of multiple factors on pathogen infestation (Meentemeyer 2008; Morante-Filho et al. 2016Dillon and Meentemeyer 2019).

Here, we tested the direct and indirect effects of landscape features, tree diversity, host density and leaf traits on pathogen infestation using Marssonina leaf spot of poplars as a case study of an endemic fungal disease. Marssonina leaf spot is induced by Drepanopeziza populi (formerly Marssonina populi), a specialist foliar pathogen, and is one of the most widespread and severely damaging diseases of poplars. This pathogen infection is more commonly known as 'black leaf spot' due to the way that it :ommonly infected poplar host in study area, but other poplar 
species (i.e., Populus alba L.) are resistant to suffering from this pathogen. We hypothesized that biotic factors (i.e., tree diversity and host density) would affect disease prevalence/severity more strongly than abiotic landscape features, but their effects on pathogen infestation were mediated by leaf traits, i.e., leaf area, SLA, and leaf dry matter content (LDMC). Specifically, we test the following hypotheses: (1) greater density of poplar hosts ( $P$. laurifolia) will generate greater pathogen load and directly increase disease prevalence; (2) disease prevalence in poplars will be lower in mixed stands than in pure forest stands; (3) leaf area and SLA will have a positive effect on pathogen load and disease severity of $D$. populi, but LDMC will have a negative effect on pathogen load and disease severity; (4) landscape features (e.g., forest cover) will indirectly affect pathogen load, disease prevalence and severity by influencing host density, tree diversity and leaf traits. By elucidating the relative effects of biotic and abiotic factors on pathogen infestation, our results will offer key insights into risk predictions and control strategies for damaging endemic diseases.

\section{Materials And Methods}

\section{Study site and plot selection}

This study was conducted in natural forests along the Irtysh River in Altay region of the Northern Xinjiang, Northwest China (Fig. 1). This region, a typical ecoregion with a temperate continental climate, contains a large number of forest patches, which are generally dominated by $P$. laurifolia, accompanied by other tree species such as $P$. alba. Poplar trees (Populus spp.) are one of the most important components of riparian ecosystems throughout most of the North China, shaping the environment of special habitats and providing many ecosystem services (Philippe and Bohlmann 2007; Wang et al. 2021). But in recent decades, the region has undergone extensive degradation of native forest resulting in a highly fragmented landscape due to the enlarged farmland size and the increase of grazing intensity.

The special climate conditions (e.g., drought, high temperature, and large temperature difference in the growing season) within study area also threaten the survival and regeneration of native forest trees. In addition to the anthropogenic disturbances and environmental changes, a wide variety of endemic insect herbivores and fungal pathogens had adverse effects on dominant poplar species in this region (Wang et al. 2021). In recent years, there has been a decline in the health of $P$. laurifolia associated with Marssonina leaf spot, though tree death is rare unless there are several consecutive years of other stresses such as drought and Cytospora canker. The disease cycle of $D$. populi takes one year, and its incidence rate is highest after high temperatures and periods of precipitation when spores are generally available during August every year.

To identify suitable locations for study sites in areas with known tree presence and disease infection, a desktop study was conducted based on recent satellite images (European Sentinel-2A, from 2020). Potential study sites were visited and visually assessed to confirm suitability. A ground survey was then carried out in 2020 on sites with tree presence to check for the presence of host poplars, and thus a total Loading [MathJax]/jax/output/CommonHTML/jax.js ere found to be appropriate locations for the field survey. We 
established a $30 \times 30 \mathrm{~m}$ sampling plot in each of 30 study sites harbouring one of two forest stand types: pure stands ( $\mathrm{n}=15$ plots) in which $P$. laurifolia was the main species, and mixed stands $(\mathrm{n}=15$ plots) consisting of $P$. laurifolia and $P$. alba where the former was abundant (Fig. 1). Plot locations were spaced at least $600 \mathrm{~m}$ apart to avoid sampling at the spatial scale within which pathogen infection is known to be clustered (Wang et al. 2021). Furthermore, plots were located in forest stands with varying levels of forest cover across the surrounding landscapes, and the remaining landscape is characterized by grasslands, shrublands, agricultural areas and human settlements.

\section{Landscape and tree community characteristics}

Around each woodland plot, we quantified landscape heterogeneity within a circular buffer of $300 \mathrm{~m}$ radius using a sample site-landscape approach (Fahrig 2013). We selected a $300 \mathrm{~m}$ radius area to measure landscape features because previous research had shown that spatial pattern of host vegetation most strongly predicted D. populi disease level at this scale (Wang et al. 2021). This radius distance was also chosen to avoid sampling overlap between adjacent plots, which is needed to make accurate landscape-scale inferences (Eigenbrod et al. 2011). We classified land-cover types into poplar woodland, farmlands, grasslands, shrublands, and human settlements by processing remotely sensed data acquired from the Sentinel-2A satellite in July 2020. We defined human settlements as buildings, roads, and man-made streams. Analysis of landscape heterogeneity requires quantification of the configuration of land-cover types, and a large number of landscape metrics have been developed for this purpose. However, no single metric captures all information about landscape pattern, and strong correlations between many metrics make choosing an appropriate metric difficult. Thus, we quantified total area (i.e., forest cover) and perimeter : area ratio (PARA) of poplar woodland using Fragstats 4.2 to describe the woodland size and what degree trees were isolated or within a tree stand. Furthermore, the distance of each plot from the river (i.e., distance to river) was computed from remotely sensed data in ArcGIS 10.5 and defined as the shortest linear distance between the plot edge and the river bank.

All trees within each plot with a diameter at breast height $(\mathrm{DBH})>5 \mathrm{~cm}$ were measured, and the species identity was recorded to determine tree species composition (i.e., pure or mixed forest stands). We also estimated poplar host density as the number of $P$. laurifolia stems per hectare based on the number of stems with a $\mathrm{DBH}>5 \mathrm{~cm}$ rooted in the plot area.

\section{Leaf sampling and measurements}

As small brownish spots appear on infected leaves in early August, a field survey was undertaken during the peak D. populi symptom expression between middle August and early September in 2020 to measure pathogen load, disease prevalence and severity in $P$. laurifolia trees within each $30 \times 30 \mathrm{~m}$ plot. First, we recorded the number of $P$. laurifolia trees with symptomatic leaves, and calculated disease prevalence (proportion of symptomatic stems) by dividing symptomatic stems by the total number of $P$. laurifolia trees within each plot. Given that symptomatic stems in study area exhibited distinctly different levels of D. populi infection, assessing an individual as only infected or uninfected was deemed too coarse to examine variations in disease severitv among different plots. Thus, five symptomatic stems were Loading [MathJax]/jax/output/CommonHTML/jax.js 
selected randomly in each plot, with locations being chosen in the central area of each plot to avoid edge effects. Four branches were sampled growing in opposite directions from the lower and upper-tree layer of each individual (Hantsch et al. 2014a), and 30 leaves were collected per branch. We quantified pathogen load by counting the number of symptomatic leaves out of 120 leaves on each individual. Then, five leaves were haphazardly chosen on each branch, and the percentage of leaf area infected by pathogen was visually estimated and classified into seven classes: (1) $0 \%$, (2) $1-5 \%$, (3) $6-10 \%$, (4) $11-$ $25 \%$, (5) $26-50 \%$, (6) 51-75\%, (7) 76-100\%, after previous authors (Hantsch et al. 2013, 2014a; Field et al. 2020). Disease severity per tree individual was calculated by averaging damage percentage of all analysed leaves (20 leaves) of the individual. The average proportion of leaf area infected by pathogen, sometimes referred to as severity index or infection incidence, is a common measure in disease ecology (Rottstock et al. 2014; Liu et al. 2016). The pathogen load variable provides information on the abundance of $D$. populi in a plot, reflecting the degree to which a plot can serve as a source for future infections, while the prevalence variable examines risk of infection for individual $P$. laurifolia trees at a given site, and the disease severity category depicts intensity of pathogen infestation.

To measure three leaf traits: leaf area, SLA and LDMC, 10 additional undamaged, mature, and fully expanded leaves were collected from each of five individuals. Sampled leaves were stored in sealed moist plastic bags and measurements were done within $12 \mathrm{~h}$ after collection. Leaf area was calculated by photographing fresh leaves against a scale and using ImageJ software version 1.53 (Muiruri et al. 2019). Fresh weight (FW) was weighed with an electronic balance, and dry weight (DW) was obtained after drying leaves for $24 \mathrm{~h}$ in an oven at $60^{\circ} \mathrm{C}$. SLA was measured as the ratio of (upper) leaf area $\left(\mathrm{cm}^{2}\right)$ divided by the leaf DW (g). LDMC was computed as the ratio of leaf DW to FW. Leaf area, SLA and LDMC were first calculated at the level of individual trees and then averaged per plot.

\section{Statistical analyses}

All statistical analyses were conducted in R v.4.0.2 (R Core Team 2020), using the $n / m e$, MuMIn and piecewiseSEM packages for model fitting (Lefcheck et al. 2018; Pinheiro et al. 2018; Bartoń 2019). To assess the hypothesized relationships between biotic and abiotic drivers of pathogen infestation in the Marssonina leaf spot system, we used structural equation modeling (SEM) as it enables conceptualizing and examining direct and indirect effects of multiple processes in ecological systems (Grace et al. 2010). Due to the lack of theoretical and empirical evidence of multiple drivers of this endemic disease, the first step of our analyses was intended to determine if changes in landscape, tree community characteristics and poplar leaf traits could result in differences in pathogen infestation.

In a preliminary step, we fitted separate linear mixed-effect models (LMM) to identify the effects of landscape and tree community characteristics on leaf traits as well as their effects on pathogen load, disease prevalence, and disease severity. Fixed effects were forest cover, PARA, distance to river, host density, and forest type, and additional fixed effects (leaf area, SLA and LDMC) were added to the full models of pathogen load, disease prevalence and disease severity. Plot identity was assigned as a random factor to account for the non-independence of samples from the same plot. For each response

Loading [MathJax]/jax/output/CommonHTML/jax.js h applied model simplification by sequentially removing non- 
significant terms to determine the best-fitting model via Akaike's Information Criterion corrected for small sample size (AICC) (Grueber et al. 2011). Finally, we estimated model coefficients of the simplified model and calculated marginal $R^{2}$ and conditional $R^{2}$ for fixed effects $\left(R_{m}^{2}\right)$ and fixed plus random effects $\left(R_{C}^{2}\right)$. Response variables were log-transformed to satisfy the assumptions of normality.

Predictor variables with significant coefficients were used in SEM to determine whether landscape and tree community effects act directly or indirectly through changes in leaf traits. Using the results of preliminary analyses (Table S1) and published knowledge of endemic foliar fungal disease dynamics, we first developed a structural model describing hypothesized direct and indirect relationships between forest cover, tree community, leaf traits, and disease (Fig. 2) and assessed this model structure using path analysis (Shipley 2009). We considered forest cover as exogenous predictors. Subsequently, tree diversity, host density, and two leaf traits (i.e., SLA and LDMC) served as endogenous predictors. We then used the piecewiseSEM package to evaluate our model because it permits the inclusion of hierarchical data by piecing multiple mixed-effect models into one causal framework (Lefcheck 2016). Based on the preliminary analyses, we modeled all response variables as normally distributed. We assessed the overall fit of the initial piecewise SEM using directional separation (d-separation) tests, which determines the probability of informative path missing from hypothesized network (Shipley 2009). Models were considered rejected if $\chi^{2}$-test of Fisher's $C$-statistic fell below the significance level $(P<0.05)$, indicating that the model is inconsistent with the data. Finally, the standardized path coefficients $(\beta)$ and $p$ values were used to assess the significance of individual predictors within the final model. $\beta$ coefficients scaled by the standard error of the variables allow direct comparisons between relationships that are measured on different scales (Grace et al. 2010). The coefficient of determination $\left(R^{2}\right)$ shows the variance of each endogenous variable due to effect of the other variables (Morante-Filho et al. 2016).

\section{Results}

Overall, $67 \%$ of the sampled leaves ( $n=18000$ leaves) showed signs of pathogen damage, with an average of $14.33 \% \pm 6.93 \%$ (mean $\pm S D$ ) of infected area per leaf. Biotic factors of tree diversity, host density, and leaf traits had stronger effects on pathogen infestation than abiotic factors, and abiotic landscape structure significantly influenced tree community characteristics (Fig. 3). Forest cover at the landscape scale directly increased tree diversity and host density (Fig. 4a), but had no direct effects on pathogen infestation. The results of $d$-separation test indicated that only leaf traits directly affected disease severity. SLA had a positive effect on disease severity (Fig. 4b), whereas LDMC had a negative effect (Fig. 4c). And we found that disease prevalence was most strongly affected by the biotic factors of tree diversity, but also was influenced by pathogen load. However, they had opposite direct effects on disease prevalence with greater tree diversity resulting in lower disease prevalence and greater pathogen load resulting in greater disease prevalence (Fig. 4d). Host density had the strongest direct effect on pathogen load (Fig. 4e), but pathogen load was also influenced directly by leaf traits with greater SLA resulting in greater pathogen load (Fig. 4f) and greater LDMC resulting in lower pathogen load (Fig. 4g). 
Table 1 Standardized estimates of path coefficients from the fitted path model in Fig. 3 for pathogen load, disease prevalence and disease severity. Estimate, estimated path coefficient; SE, standard error; $p$ value, $p$-value of the estimated coefficient; Std. Estimate, standardized estimate of the path coefficient; SLA, specific leaf area; LDMC, leaf dry matter content. Significant effects are in bold text.

\begin{tabular}{|llllll|}
\hline Response & Predictor & Estimate & SE & $p$-value & Std. Estimate \\
\hline Host density & Forest cover & 0.056 & 0.008 & $<0.001$ & $\mathbf{0 . 8 1}$ \\
\hline Tree diversity & Forest cover & 0.018 & 0.006 & $\mathbf{0 . 0 0 7}$ & $\mathbf{0 . 4 8}$ \\
\hline SLA & Forest cover & 0.517 & 0.272 & 0.068 & 0.54 \\
\hline SLA & Host density & -4.356 & 3.732 & 0.254 & -0.32 \\
\hline SLA & Tree diversity & -8.757 & 4.619 & $\mathbf{0 . 0 0 6}$ & $-\mathbf{0 . 3 5}$ \\
\hline LDMC & Forest cover & -0.002 & 0.001 & 0.152 & -0.27 \\
\hline LDMC & Tree diversity & 0.073 & 0.034 & $\mathbf{0 . 0 4 1}$ & $\mathbf{0 . 3 9}$ \\
\hline Pathogen load & Host density & 11.640 & 2.634 & $<0.001$ & $\mathbf{0 . 5 0}$ \\
\hline Pathogen load & SLA & 0.471 & 0.224 & $\mathbf{0 . 0 4 5}$ & $\mathbf{0 . 2 8}$ \\
\hline Pathogen load & LDMC & -70.061 & 32.516 & $\mathbf{0 . 0 4 1}$ & $-\mathbf{0 . 3 1}$ \\
\hline Disease prevalence & Host density & 2.157 & 5.161 & 0.679 & 0.09 \\
\hline Disease prevalence & Tree diversity & -24.18 & 11.235 & $\mathbf{0 . 0 4 1}$ & $\mathbf{- 0 . 5 4}$ \\
\hline Disease prevalence & Pathogen load & 0.161 & 0.339 & $\mathbf{0 . 0 3 9}$ & $\mathbf{0 . 1 5}$ \\
\hline Disease severity & Tree diversity & -1.163 & 1.948 & 0.556 & -0.09 \\
\hline Disease severity & SLA & 0.242 & 0.086 & $\mathbf{0 . 0 0 9}$ & $\mathbf{0 . 4 6}$ \\
\hline Disease severity & LDMC & -32.908 & 11.906 & $\mathbf{0 . 0 1 0}$ & $\mathbf{- 0 . 4 6}$ \\
\hline
\end{tabular}

From the 16 pathways present in the best model, 11 were significant and consistent with our predictions. The statistically insignificant hypothesized relationships included those between forest cover and leaf traits, host density and SLA, host density and disease prevalence, and tree diversity and disease severity. Specifically, this model explained $65 \%$ of host density, $23 \%$ of tree diversity, $33 \%$ SLA, $32 \%$ of LDMC, $74 \%$ of pathogen load, $51 \%$ of disease prevalence, and $62 \%$ of disease severity . Greater forest cover caused higher host density $(\beta=0.81)$, which had a positive effect on pathogen load $(\beta=0.50)$. However, pathogen load was also negatively related to $\operatorname{LDMC}(\beta=-0.31)$ and positively related to SLA $(\beta=0.28)$. Furthermore, forest cover had a positive direct effect on tree diversity $(\beta=0.48)$, which had a negative effect on disease prevalence $(\beta=-0.54)$ and caused different effects on leaf traits. SLA was negatively related to tree diversity $(\beta=-0.35)$, but LDMC was positively related to tree diversity $(\beta=0.39)$. Disease 
prevalence was also positively related to pathogen load $(\beta=0.15)$. Finally, disease severity was positively related to SLA $(\beta=0.46)$ and negatively to LDMC $(\beta=-0.46)$ (Fig. 3; Table 1).

\section{Discussion}

Our study is the first to analyse the effects of landscape and tree community characteristics on important leaf traits and to explore their role in driving endemic pathogen damage in a riparian forest ecosystem. We demonstrated that pathogen infestation in the Marssonina leaf spot disease system was more strongly affected by tree community characteristics and leaf traits, but tree community was shaped by abiotic landscape features, i.e., plots with higher surrounding forest cover had higher host density and tree diversity. Higher host densities increased pathogen load, which resulted in greater disease prevalence in susceptible poplars, but this was countered by a relatively strong negative effect of tree diversity. Tree diversity also reduced SLA but increased LDMC. Leaf traits simultaneously influenced pathogen load and disease severity, with SLA increasing both of them, but LDMC reducing both of them.

We found that, although host poplar density was the strongest driver of pathogen load (symptomatic leaf count) in the plot, there is no strong support for another part of our first hypothesis, which stated that an increase in host density of $P$. laurifolia will result in an increase in the degree of disease prevalence. Several studies indicated that individual variation in host tree susceptibility can be obscured at the plot scale by tree community characteristics, reinforcing our findings of host density effects on pathogen load (Meentemeyer et al. 2008; Dillon and Meentemeyer 2019). Pathogen reproduction is dependent on the tree community because of differences in tree species' competency for pathogen reproduction and tolerance of pathogen infestation. One possible mechanism by which tree community affects pathogen infestation is host density, as demonstrated by a number of observational and experimental studies on host availability of tropical and temperate tree species (Seiwa et al. 2008; Yamazaki et al. 2009; Bagchi et al. 2010). Specialized fungal pathogens are not expected to maintain a higher level of a pathogen population with increasing tree species diversity because of decreasing host plant densities, which translates into reduced host resource availability (Benítez et al. 2013; Hantsch et al. 2014a). Furthermore, our results confirmed the findings of Chanthorn et al. (2013), who also failed to detect significant effects of host density on the infection rate of a host-specific fungus on Cinnamomum subavenium trees. As several studies have demonstrated a decline in pathogen transmission with decreasing host availability (Mundt et al. 2011; Cobb et al. 2012), the detected absence of host density effects on disease prevalence was unexpected. As our results regarding host density effects oppose the previous findings on density dependency of infection rates of fungal pathogens, it seems that local host density does not affect the degree of disease prevalence through declining resource availability but rather through modifying the pathogen load.

Our second hypothesis, stating that disease prevalence on susceptible poplars will be lower in mixed than in pure forest stands, could largely be confirmed. The negative relationship between tree diversity and disease prevalence is evidence for the dilution effect, i.e., species diversity reduces disease risk, which Keesing et al. 2006; Haas et al. 2011; Hantsch et al. 2013). 
Increasing tree diversity could reduce the encounter rate between dispersed spores and susceptible trees. Interestingly, the dilution effect did not extend to pathogen load on host poplar, and this may be because a single symptomatic host tree with thousands of leaves could support a very large pathogen load even as the only host tree among non-host trees. The magnitude of the dilution effect may be influenced by variations in individual leaf traits, but we did not detect obviously in our models. The effects of local tree diversity on fungal infestation in our study may also be subsumed in associational resistance hypothesis (Field et al. 2020), which states that a diverse tree community reduces pathogen development due to structural heterogeneity, especially through a higher microclimatic heterogeneity. As microclimatic properties can be affected by varying canopy size and structure of neighbouring plant species in a particular tree community, diverse tree size may be considered as one of the most important factors determining pathogen development (Jactel et al. 2009; Calonnec et al. 2013; Hantsch et al. 2014a). Our study is the first to demonstrate associational resistance to endemic fungal pathogens by tree species in natural riparian forests at the stand level, and reinforces the previous finding in the foliar disease system by using a real-world data set from spatially diverse plots with different forest stand types.

Alongside tree community characteristics, leaf trait is also an important driver of the disease dynamics. This study demonstrated a positive effect of SLA on pathogen load and disease severity and a negative effect of LMDC on them. These correlations could be largely explained by leaf morphology. As tree leaves with low SLA and high LMDC contain more structural carbohydrates, such as lignin and cellulose in their cell walls (Mediavilla et al. 2008), these leaves may be not colonized by spot fungi as easily as leaves with thinner cell walls. In contrast, it can be speculated that leaves with high SLA, low LMDC and thin cell walls contain more non-structural carbohydrates in their cell sap, which are very important nutrients for obligate plant pathogens (Berger et al. 2007). Once infection occurs, these carbohydrates and others suitable nutrients (e.g., nitrogen and amino acids) are easily available for pathogens and therefore will promote disease severity in leaves with high SLA and low LMDC (Toome et al. 2010). Additionally, local tree diversity had strong effects on SLA and LMDC. Since host trees are the tallest species in this study, mixed stands have a higher proportion of shorter tree species. Thus, host trees surrounded by short heterospecific neighbouring trees experience the higher light intensities and produce leaves with lower SLA, and they even experience the unfavourable conditions with water stress and produce leaves with higher LDMC (Muiruri et al. 2019). However, within pure stands, higher proportion of taller host trees may shape a shady environment, and shaded leaves found lower in the host canopy have larger SLA and lower LMDC (Legner et al. 2014) and are preferred by fungal pathogens. Therefore, variations in leaf traits with tree diversity as a result of reduced canopy cover around host tree may mediate tree community effects on this endemic fungal disease.

Predicting spatial dynamics of disease spread and severity in forest ecosystems requires knowledge of not only tree community characteristics and individual leaf traits, but also the spatial arrangement and composition of vegetation surrounding plot (Condeso and Meentemeyer 2007; Grosdidier et al. 2020). As natural plant communities are embedded within heterogeneous landscapes, ecological processes occurring at larger spatial extents could play a key role in shaping disease dynamics at local scales Loading [MathJax]/jax/output/CommonHTML/jax.js . 2012; Dillon et al. 2014). Specifically, pathogen spread and 
disease expression has been shown to be influenced by landscape features including the spatial structure of host populations (Meentemeyer et al. 2008), as well as spatial heterogeneity in the abiotic environment including topographic and climate effects (Haas et al. 2016; Dillon et al. 2019). However, we found that landscape characteristics had no direct influence on pathogen infestation. Our path analysis revealed that locations with greater forest cover surrounding a plot indirectly reduced pathogen load by having lower host density, and exerted an indirect negative effect on disease prevalence via tree diversity. The influence of land-cover changes on plant-pathogen interactions in forests has rarely been studied, but a previous research suggested that landscape features such as woodland cover influences disease spread through forest structure, host density, and understory microclimate (Meentemeyer et al. 2008). The simplification of stand structure in deforested and fragmented landscapes is relatively well known (Arroyo-Rodríguez et al. 2006; Morante-Filho et al. 2016), also in the study region, where reduced forest cover is related to the decline of host density and tree diversity.

\section{Conclusions}

Although indirect effect of tree community characteristics on leaf damage in forests was also found in previous studies, our unique contribution is that we demonstrated that tree community-pathogen infestation relationship is most probably mediated by leaf traits in a landscape-scale study. Despite the complex nature involved in these ecological processes, and several limitations for controlling many ecological variables shaping disease expression in natural patches across multiple local and landscape scales, we demonstrates that forest cover surrounding host trees affects pathogen infestation indirectly, through the variations of tree community composition and the associated changes in the poplar leaf traits. As landscape-scale changes can limit the growth and regeneration of plant assemblages, we would expect that forest remnants in landscapes with different forest cover would have different successional trajectories, potentially leading to divergence in plant species composition and leaf traits. More research on leaf traits accounting for functional differences between forest stands under different landscape-scale context can improve our understanding of tree diversity-disease resistance relationships, and enhance our ability to predict and reduce pathogen infestation of endemic plant diseases in natural forests.

\section{Abbreviations}

FW: fresh weight; DW: dry weight; DBH: diameter at breast height; LDMC: leaf dry matter content; LMM: linear mixed-effect model; : conditional R²; : marginal R²; SEM: Structural equation modeling; SLA: Specific Leaf Area

\section{Declarations}

\section{Ethics approval and consent to participate}

Not applicable. 


\section{Consent for publication}

Not applicable.

\section{Availability of data and materials}

The datasets used and/or analyzed during the current study are available from the corresponding author on reasonable request.

\section{Competing interests}

The authors declare that they have no known competing financial interests or personal relationships that could have appeared to influence the work reported in this paper.

\section{Funding}

This study was supported by the National Key Research and Development Program (grant numbers: 2017YFD0600105).

\section{Authors' contributions}

$\mathrm{BW}, \mathrm{CT}$, and $\mathrm{YL}$ designed the research; BW conducted the field work; BW analyzed data and drafted the manuscript; CT and YL revised the manuscript. All authors read and approved the final manuscript.

\section{Acknowledgements}

The authors are deeply grateful to Chunjiang Li for providing sampling tools and his assistance in collecting data. We also thank local herdsmen for their support during data sampling.

\section{References}

1. Al Afas, N., Marron, N., \& Ceulemans, R. (2007). Variability in Populus leaf anatomy and morphology in relation to canopy position, biomass production, and varietal taxon. Annals of Forest Science, 64, 521-532. https://doi.org/10.1051/forest:2007029

2. Arroyo-Rodríguez, V., Melo, F.P.L., Martínez-Ramos, M., Bongers, F., Chazdon, R.L., Meave, J.A., Norden, N., Santos, B.A., Leal, I.R., \& Tabarelli, M. (2016). Multiple successional pathways in human-modified tropical landscapes: new insights from forest succession, forest fragmentation and landscape ecology research. Biological Reviews, 92(1), 326-340. https://doi.org/10.1111/brv.12231

3. Assefa, A., \& Abate, D. (2018). Assessment of wounding factors (natural and anthropogenic) of Juniperus procera and their relation to disease occurrence of Pyrofomes demidoffii in some afromontane forests of Ethiopia. Forest Ecology and Management, 409, 361371. https://doi.org/10.1016/j.foreco.2017.11.031 
4. Bagchi, R., Swinfeld, T., Gallery, R.E., Lewis, O.T., Gripenberg, S., Narayan, L. \& Freckleton, R.P., (2010). Testing the Janzen-Connell mechanism: pathogens cause overcompensating density dependence in a tropical tree. Ecology Letters, 13(10), 1262-1269. https://doi.org/10.1111/j.14610248.2010.01520.x

5. Bartoń, K. (2019). MuMIn: Multi-Model Inference. R package version 1.43.15. https://CRAN.Rproject.org/package=MuMIn

6. Benítez M.-S., Hersh, M.H., Vilgalys, R., \& Clark, J.S. (2013). Pathogen regulation of plant diversity via effective specialization. Trends in Ecology \& Evolution, 28(12), 705-711. https://doi.org/10.1016/j.tree.2013.09.005

7. Berger, S., Sinha, A.K., \& Roitsch, T., (2007). Plant physiology meets phytopathology: plant primary metabolism and plant-pathogen interactions. Journal of Experimental Botany, 58(15-16), 40194026. https://doi.org/10.1093/jxb/erm298

8. Burgess, T.I., \& Wingfield, M.J. (2017). Pathogens on the move: A 100-year global experiment with planted eucalypts. BioScience, 67(1), 14-25. https://doi.org/10.1093/biosci/biw146

9. Calonnec, A., Burie, J.B., Langlais, M., Guyader, S., Saint-Jean, S., Sache, I., \& Tivoli, B. (2013). Impacts of plant growth and architecture on pathogen processes and their consequences for epidemic behaviour. European Journal of Plant Pathology, 135, 479-497. https://doi.org/10.1007/s10658012-0111-5

10. Castello, J.D., Leopold, D.J., \& Smallidge, P.J. (1995). Pathogens, patterns, and processes in forest ecosystems: pathogens influence and are influenced by forest development and landscape characteristics. BioScience, 45(1), 16-24. https://doi.org/10.2307/1312531

11. Cobb, R.C., Filipe, J.A.N., Meentemeyer, R.K., Gilligan, C.A., \& Rizzo, D.M. (2012). Ecosystem transformation by emerging infectious disease: loss of large tanoak from California forests. Journal of Ecology, 100(3), 712-722. https://doi.org/10.1111/j.1365-2745.2012.01960.x

12. Cobb, R.C., \& Metz, M.R. (2017). Tree diseases as a cause and consequence of interacting forest disturbances. Forests, 8(5), 147. https://doi.org/10.3390/f8050147

13. Condeso, T.E., \& Meentemeyer, R.K. (2007). Effects of landscape heterogeneity on the emerging forest disease sudden oak death. Journal of Ecology, 95(2), 364-375. https://doi.org/10.1111/j.1365-2745.2006.01206.x

14. Dillon, W.W., Haas, S.E., Rizzo, D.M., \& Meentemeyer, R.K. (2014). Perspectives of spatial scale in a wildland forest epidemic. European Journal of Plant Pathology, 138, 449465.https://doi.org/10.1007/s10658-013-0376-3

15. Dillon, W.W., \& Meentemeyer, R.K. (2019). Direct and indirect effects of forest microclimate on pathogen spillover. Ecology, 100(5), e02686. https://doi.org/10.1002/ecy.2686

16. Eigenbrod, F., Hecnar, S. J., \& Fahrig, L. (2011). Sub-optimal study design has major impacts on landscape-scale inference. Biological Conservation, 144(1), 298-305.

https://doi.org/10.1016/j.biocon.2010.09.007 
17. Ferrenberg, S. (2016). Landscape features and processes influencing forest pest dynamics. Current Landscape Ecology Reports, 1, 19-29. https://doi.org/10.1007/s40823-016-0005-x

18. Field, E., Castagneyrol, B., Gibbs, M., Jactel, H., Barsoum, N., Schönrogge, K., \& Hector, A. (2020). Associational resistance to both insect and pathogen damage in mixed forests is modulated by tree neighbour identity and drought. Journal of Ecology, 108(4), 1511-1522. https://doi.org/10.1111/1365-2745.13397

19. Ghelardini, L., Pepori, A.L., Luchi, N., Capretti, P., \& Santini, A. (2016). Drivers of emerging fungal diseases of forest trees. Forest Ecology and Management, 381, 235246.https://doi.org/10.1016/j.foreco.2016.09.032

20. Grace, J.B., Anderson, T.M., Olff, H., \& Scheiner, S.M. (2010). On the specification of structural equation models for ecological systems. Ecological Monographs, 80(1), 67-87. https://doi.org/10.1890/09-0464.1

21. Grosdidier, M., Scordia, T., loos, R., \& Marçais, B. (2020). Landscape epidemiology of ash dieback. Journal of Ecology, 108(5), 1789-1799. https://doi.org/10.1111/1365-2745.13383

22. Grueber, C.E., Nakagawa, S., Laws, R.J., \& Jamieson, I.G. (2011). Multimodel inference in ecology and evolution: challenges and solutions. Journal of Evolutionary Biology, 24(4), 699-711. https://doi.org/10.1111/j.1420-9101.2010.02210.x

23. Haas, S.E., Hooten, M.B., Rizzo, D.M., \& Meentemeyer, R.K. (2011). Forest species diversity reduces disease risk in a generalist plant pathogen invasion. Ecology Letters, 14(11), 11081116.https://doi.org/10.1111/j.1461-0248.2011.01679.x

24. Haas, S.E., Cushman, J.H., Dillon, W.W., Rank, N.E., \& Meentemeyer, R.K. (2016). Effects of individual, community and landscape drivers on the dynamics of a wildland forest epidemic. Ecology, 97(3), 649-660. https://doi.org/10.1890/15-0767.1

25. Hansen, E.M. (1999). Disease and diversity in forest ecosystems. Australasian Plant Pathology, 28, 313-319. https://doi.org/10.1071/ap99050

26. Hantsch, L., Bien, S., Radatz, S., Braun, U., Auge, H, \& Bruelheide, H. (2014a). Tree diversity and the role of non-host neighbour tree species in reducing fungal pathogen infestation. Journal of Ecology, 102(6), 1673-1687. https://doi.org/10.1111/1365-2745.12317

27. Hantsch, L., Braun, U., Haase, J., Purschke, O., Scherer-Lorenzen, M., \& Bruelheide, H. (2014b). No plant functional diversity effects on foliar fungal pathogens in experimental tree communities. Fungal diversity, 66, 139-151. https://doi.org/10.1007/s13225-013-0273-2

28. Hantsch, L., Braun, U., Scherer-Lorenzen, M., \& Bruelheide, H. (2013). Species richness and species identity effects on occurrence of foliar fungal pathogens in a tree diversity experiment. Ecosphere, 4(7), 1-12. https://doi.org/10.1890/ES13-00103.1

29. Holdenrieder, O., Pautasso, M., Weisberg, P.J., \& Lonsdale, D. (2004). Tree diseases and landscape processes: the challenge of landscape pathology. Trends in Ecology and Evolution, 19(8), 446452.https://doi.org/10.1016/j.tree.2004.06.003 
30. Jactel, H., Nicoll, B. C., Branco, M., Gonzalez-Olabarria, J.R., Grodzki, W., Långström, B., Moreira, F., Netherer, S., Orazio, C., Piou, D., Santos, H., Schelhaas, M.J., Tojic, K., \& Vodde, F. (2009). The influences of forest stand management on biotic and abiotic risks of damage. Annals of Forest science, 66(7), 701. https://doi.org/10.1051/forest/2009054

31. Keesing, F., Holt, R.D., \& Ostfeld, R.S. (2006). Effects of species diversity on disease risk. Ecology Letters, 9(4), 485-498. https://doi.org/10.1111/j.1461-0248.2006.00885.x

32. Krix, D.W., \& Murray, B.R. (2018). Landscape variation in plant leaf flammability is driven by leaf traits responding to environmental gradients. Ecosphere, 9(2), e02093. https://doi.org/10.1002/ecs2.2093

33. Lefcheck, J.S. (2016). piecewiseSEM: Piecewise structural equation modelling in R for ecology, evolution, and systematics. Methods in Ecology and Evolution, 7(5), 573-579.

https://doi.org/10.1111/2041-210X.12512

34. Lefcheck, J.S., Byrnes, J., \& Grace, J. (2019). piecewiseSEM: Piecewise Structural Equation Modeling. R package version 2.1.0. https://CRAN.R-project.org/package=piecewiseSEM/

35. Legner, N., Fleck, S., \& Leuschner, C. (2014). Within-canopy variation in photosynthetic capacity, SLA and foliar $\mathrm{N}$ in temperate broad-leaved trees with contrasting shade tolerance. Trees, 28, 263-280. https://doi.org/10.1007/s00468-013-0947-0

36. Liu, X., Lyu, S., Zhou, S., \& Bradshaw, C.J.A. (2016). Warming and fertilization alter the dilution effect of host diversity on disease severity. Ecology, 97(7), 1680-1689. https://doi.org/10.1890/15-1784.1

37. McCracken, A.R., \& Dawson, M. (1992). Clonal response in Salix to Melampsora rusts in short rotation coppice plantations. European Journal of Forest Pathology, 22(1), 1928.https://doi.org/10.1111/j.1439-0329.1992.tb01332.x

38. Mediavilla, S., Garcia-Ciudad, A., Garcia-Criado, B., \& Escudero, A. (2008). Testing the correlations between leaf life span and leaf structural reinforcement in 13 species of European Mediterranean woody plants. Functional Ecology, 22(5), 787-793. https://doi.org/10.1111/j.13652435.2008.01453.x

39. Meentemeyer, R.K., Haas, S.E., \& Václavík, T. (2012). Landscape epidemiology of emerging infectious diseases in natural and human-altered ecosystems. Annual Review of Phytopathology, 50(1), 379402.https://doi.org/10.1146/annurev-phyto-081211-172938

40. Meentemeyer, R.K., Rank, N.E., Anacker, B.L., Rizzo, D.M., Cushman, J.H. (2008). Influence of landcover change on the spread of an invasive forest pathogen. Ecological Applications, 18(1), 159171.https://doi.org/10.1890/07-0232.1

41. Morante-Filho, J. C., Arroyo-Rodríguez, V., Lohbeck, M., Tscharntke, T., \& Faria, D. (2016). Tropical forest loss and its multitrophic effects on insect herbivory. Ecology, 97(12), 33153325.https://doi.org/10.1002/ecy.1592

42. Muiruri, E.W., Barantal, S., Iason, G.R., Salminen, J.-P., Perez-Fernandez, E., \& Koricheva, J. (2019). Forest diversity effects on insect herbivores: do leaf traits matter? New Phytologist, 221, 2250-2260. https://doi.org/10.1111/nph.15558 
43. Mundt, C.C., Sackett, K.E., \& Wallace, L.D. (2011). Landscape heterogeneity and disease spread: experimental approaches with a plant pathogen. Ecological Applications, 21(2), 321328.https://doi.org/10.1890/10-1004.1

44. Nguyen, D., Castagneyrol, B., Bruelheide, H., Bussotti, F, Guyot, V., Jactel, H., Jaroszewicz, B., Valladares, F., Stenlid, J., \& Boberg, J. (2016). Fungal disease incidence along tree diversity gradients depends on latitude in European forests. Ecology and Evolution, 6(8), 2426-2438. https://doi.org/10.1002/ece3.2056

45. Paap, T., Brouwers, N. C., Burgess, T.I., \& Hardy, G.E.S.J. (2017a). Importance of climate, anthropogenic disturbance and pathogens (Quambalaria coyrecup and Phytophthora spp.) on marri (Corymbia calophylla) tree health in southwest Western Australia. Annals of Forest Science, 74, 62. https://doi.org/10.1007/s13595-017-0658-6

46. Paap, T., Burgess, T.I., Calver, M., McComb, J.A., Shearer, B.L., \& Hardy, G.E.S.J. (2017b). A thirteenyear study on the impact of a severe canker disease of Corymbia calophylla, a keystone tree in Mediterranean-type forests. Forest Pathology, 47(1), e12292. https://doi.org/10.1111/efp.12292

47. Paap, T., Burgess, T.I., Rolo, V., Steel, E., \& Hardy, G.E.S.J. (2018). Anthropogenic disturbance impacts stand structure and susceptibility of an iconic tree species to an endemic canker pathogen. Forest Ecology and Management, 425, 145-153. https://doi.org/10.1016/j.foreco.2018.05.055

48. Pautasso, M., Schlegel, M., \& Holdenrieder, O. (2015). Forest health in a changing world. Microbial Ecology, 69, 826-842. https://doi.org/10.1007/s00248-014-0545-8

49. Pinheiro, J., Bates, D., DebRoy, S., \& Sarkar, D. (2018). nlme: Linear and Nonlinear Mixed Effects Models. R package version 3.1-137. https://CRAN.R-project.org/package=nlme

50. Pinon, J., Frey, P., \& Husson, C. (2006). Wettability of poplar leaves influences dew formation and infection by Melampsora larici-populina. Plant Disease, 90(2), 177-184. https://doi.org/10.1094/PD90-0177

51. Plantegenest, M., Le May, C., \& Fabre, F. (2007). Landscape epidemiology of plant diseases. Journal of the Royal Society Interface, 4(16), 963-972. https://doi.org/10.1098/rsif.2007.1114

52. Poorter, H., Niinemets, Ü., Poorter, L., Wright, I.J., \& Villar, R. (2009). Causes and consequences of variation in leaf mass per area (LMA): a meta-analysis. New Phytologist, 182(3), 565588.https://doi.org/10.1111/j.1469-8137.2009.02830.x

53. R Core Team. (2020). R: A language and environment for statistical computing. R Foundation for Statistical Computing, Vienna, Austria. https://www.r-project.org/

54. Rottstock, T., Joshi, J., Kummer, V., \& Fischer, M. (2014). Higher plant diversity promotes higher diversity of fungal pathogens, while it decreases pathogen infection per plant. Ecology, 95(7), 19071917. https://doi.org/10.1890/13-2317.1

55. Scherber, C., Eisenhauer, N., Weisser, W.W., Schmid, B., Voigt, W., et al. (2010). Bottom-up effects of plant diversity on multitrophic interactions in a biodiversity experiment. Nature, 468, 553556.https://doi.org/10.1038/nature09492 
56. Scholthof, K.B. (2007). The disease triangle: pathogens, the environment and society. Nature Reviews Microbiology, 5, 152-156. https://doi.org/10.1038/nrmicro1596

57. Seiwa, K., Miwa, Y., Sahashi, N., Kanno, H., Tomita, M., Ueno, N., \& Yamazaki, M. (2008). Pathogen attack and spatial patterns of juvenile mortality and growth in a temperate tree, Prunus grayana. Canadian Journal of Forest Research, 38, 2445-2454. https://doi.org/10.1139/X08-084

58. Setiawan, N.N., Vanhellemont, M., Baeten, L., Dillen, M., \& Verheyen, K. (2014). The effects of local neighbourhood diversity on pest and disease damage of trees in a young experimental forest. Forest Ecology and Management, 334, 1-9. https://doi.org/10.1016/j.foreco.2014.08.032

59. Shipley, B. (2009). Confirmatory path analysis in a generalized multilevel context. Ecology, 90(2), 363-368. https://doi.org/10.1890/08-1034.1

60. Sturrock, R.N., Frankel, S.J., Brown, A.V., Hennon, P.E., Kliejunas, J.T., Lewis, K.J., Worrall, J.J., Woods, A.J. (2011). Climate change and forest diseases. Plant Pathology, 60(1), 133149.https://doi.org/10.1111/j.1365-3059.2010.02406.x

61. Toome, M., Heinsoo, K., \& Luik, A. (2010). Relation between leaf rust (Melampsora epitea) severity and the specific leaf area in short rotation coppice willows. European Journal of Plant Pathology, 126, 583-588. https://doi.org/10.1007/s10658-009-9566-4

62. Turner, M.G. (1989). Landscape Ecology: The effect of pattern on process. Annual Review of Ecology and Systematics, 20,171-197. https://doi.org/10.1146/annurev.ecolsys.20.1.171

63. Turner, M.G. (2005). Landscape ecology: What is the state of the science? Annual Review of Ecology, Evolution, and Systematics, 36(1), 319-

344. https://doi.org/10.1146/annurev.ecolsys.36.102003.152614

64. Wang, B.L., Tian, C.M., \& Liang, Y.M. (2021). Mixed effects of landscape structure, tree diversity and stand's relative position on insect and pathogen damage in riparian poplar forests. Forest Ecology and Management, 479, 118555. https://doi.org/10.1016/j.foreco.2020.118555

65. Yamazaki, M., Iwamoto, S., \& Seiwa, K. (2009). Distance- and density-dependent seedling mortality caused by several diseases in eight tree species co-occurring in a temperate forest. Plant Ecology, 201, 181-196. https://doi.org/10.1007/s11258-008-9531-x

\section{Figures}


(a)
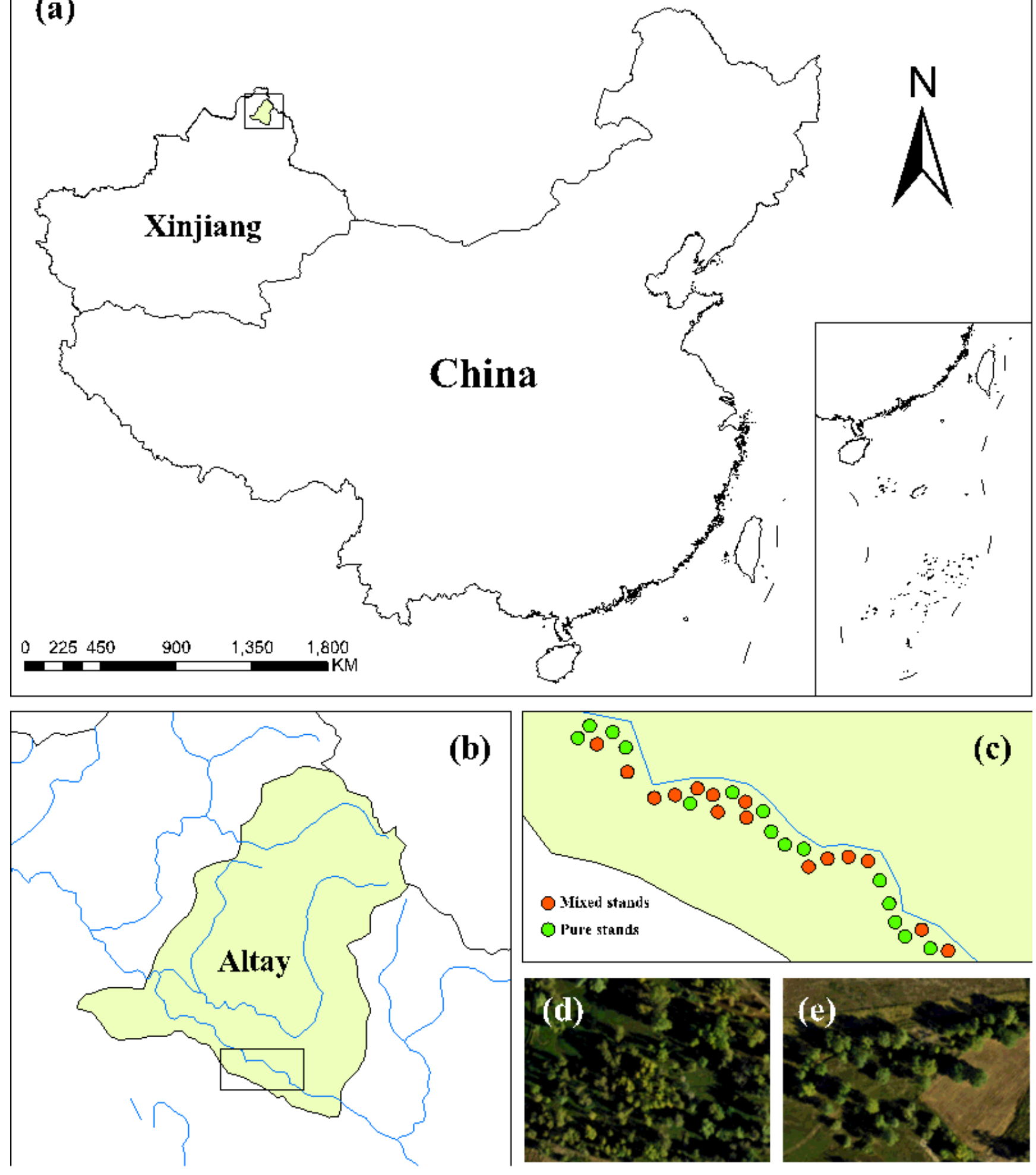

\section{Figure 1}

(a) General location of the study area in Xinjiang, Northwest China. (b) Locations for study sites in natural forests along the Irtysh River in Altay region. (c) 30 sampling plots in study sites harbouring two forest stand types: (d) mixed forest stands and (e) pure forest stands. (The blue lines on the map represent rivers). 


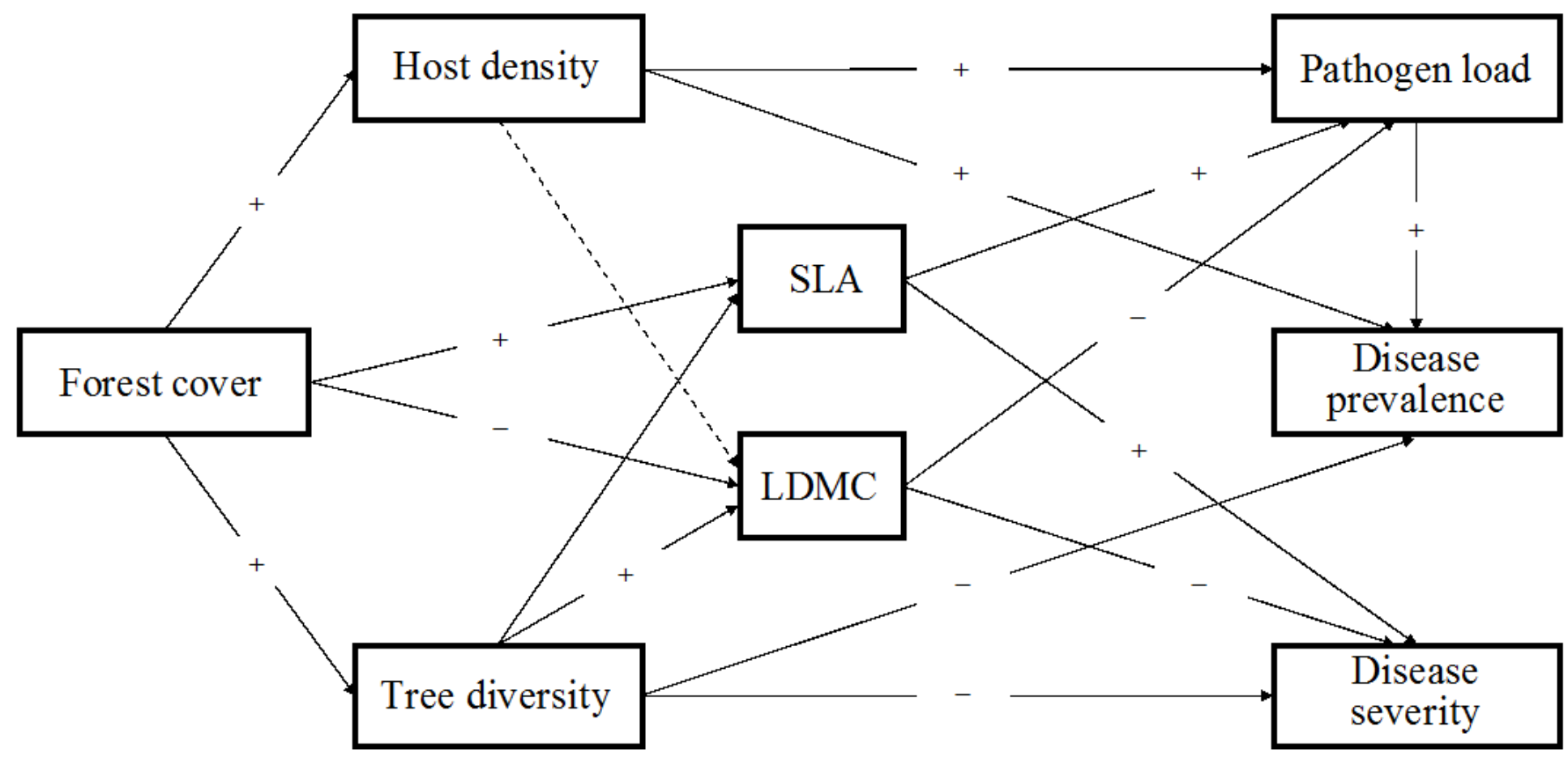

Figure 2

Conceptual path model describing the hypothesized causal relationships between factors influencing pathogen infestation in the Marssonina leaf spot disease system. Positive and negative hypothetical pathways are indicated by " + " and "-" near the arrows, respectively. SLA, specific leaf area; LDMC, leaf dry matter content.

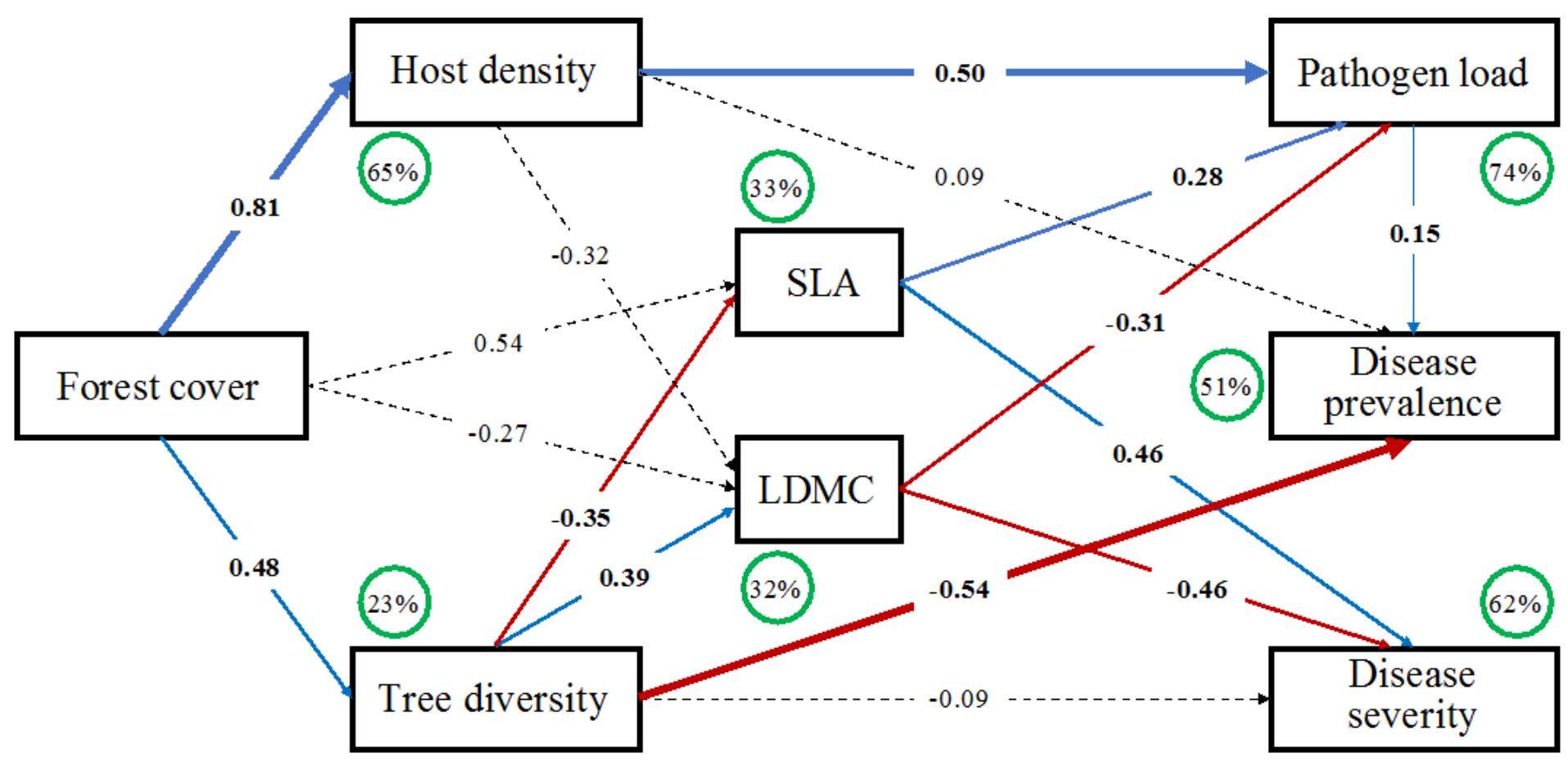

Figure 3 
Standardized coefficients for each relationship in the path model. Positive and negative pathways are indicated by blue and red lines, respectively. Dotted lines are statistically insignificant at $p<0.05$. The coefficient of determination (R2) is shown in green circles for all response variables (i.e., host density, tree diversity, SLA, LDMC, pathogen load, disease prevalence, and disease severity). Arrow thickness is scaled to the absolute value of the standardized path coefficient. SLA, specific leaf area; LDMC, leaf dry matter content. Significant effects are in bold text.
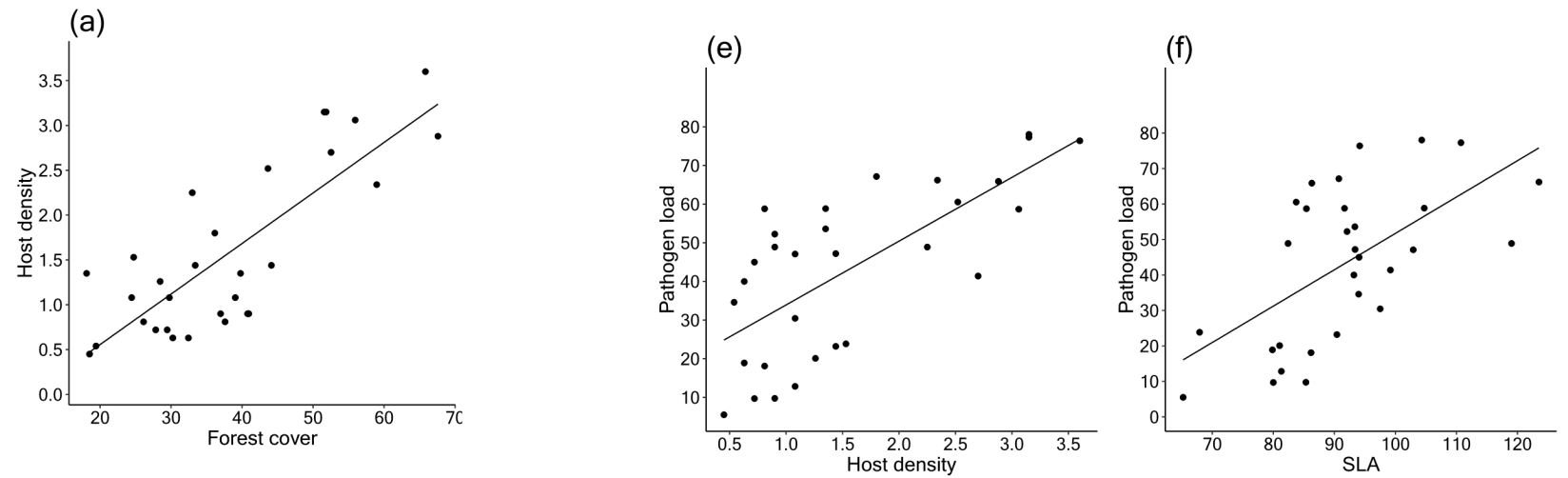

(b)

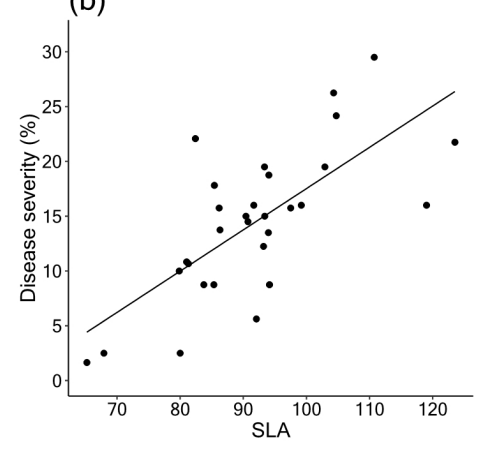

(c)
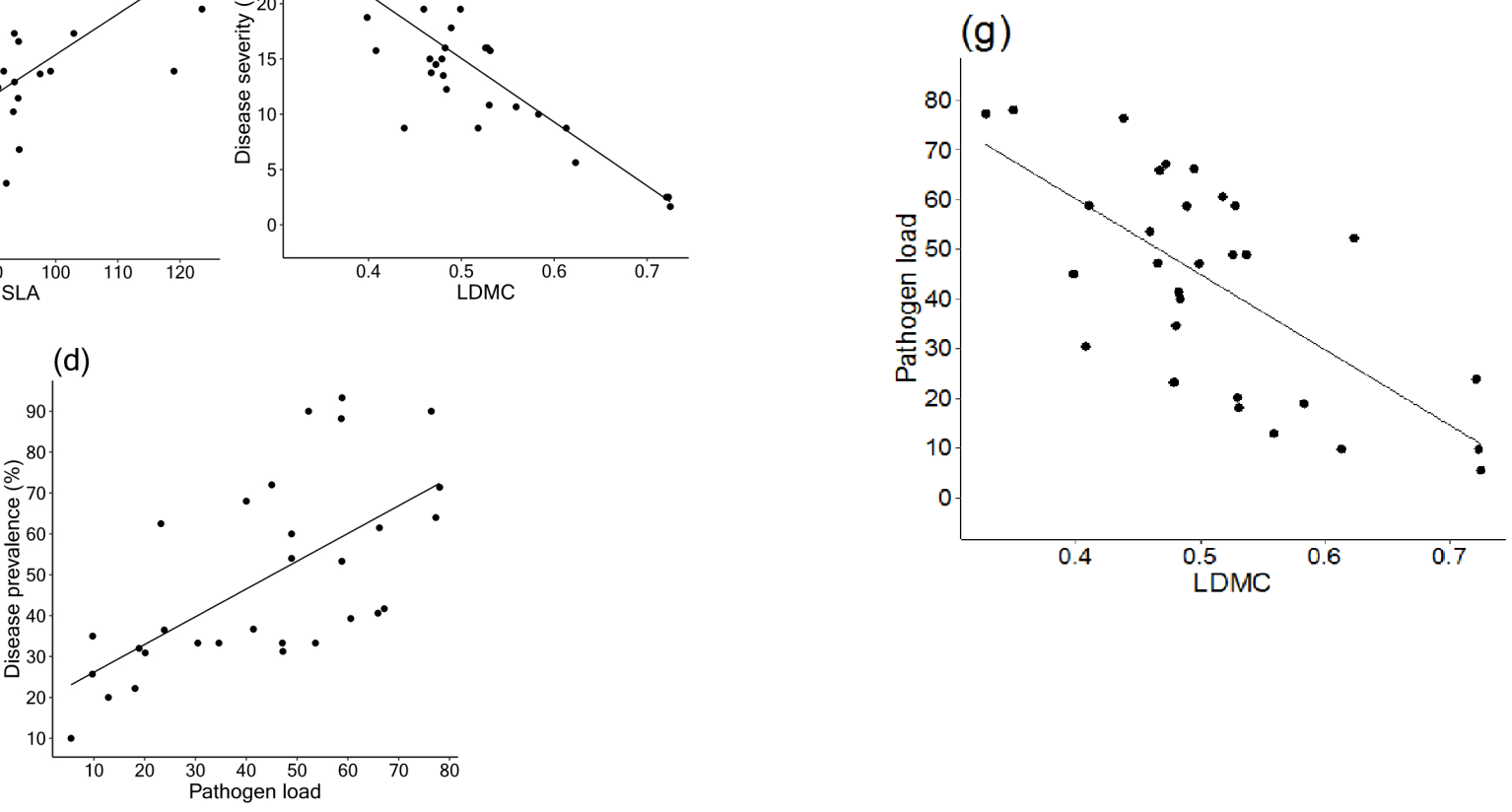

Figure 4

Plots of the predicted relationships (smooth line) for significant paths between response and explanatory variables from fitted models of the path analysis in Figure 3; (a) forest cover vs. host density, (b) SLA (specific leaf area) vs. disease severity (\%), (c) LDMC (leaf dry matter content) vs. disease severity (\%), (d) pathogen load vs. disease prevalence (\%), (e) host density vs. pathogen load, (f) SLA vs. pathogen load, (g) LDMC vs. pathogen load. 


\section{Supplementary Files}

This is a list of supplementary files associated with this preprint. Click to download.

- SupportingInformation.docx 